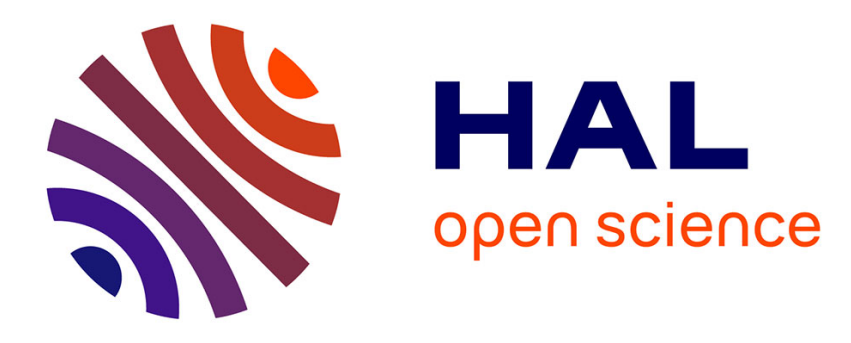

\title{
Land and Real Estate in Northeast Asia, New Approaches in an Era of Financialization
}

\author{
Natacha Aveline-Dubach
}

\section{To cite this version:}

Natacha Aveline-Dubach. Land and Real Estate in Northeast Asia, New Approaches in an Era of Financialization. Issues \& Studies, 2016, 52 (04), 10.1142/S101325111602001X . halshs-01756170

\section{HAL Id: halshs-01756170 \\ https://shs.hal.science/halshs-01756170}

Submitted on 3 Apr 2018

HAL is a multi-disciplinary open access archive for the deposit and dissemination of scientific research documents, whether they are published or not. The documents may come from teaching and research institutions in France or abroad, or from public or private research centers.
L'archive ouverte pluridisciplinaire HAL, est destinée au dépôt et à la diffusion de documents scientifiques de niveau recherche, publiés ou non, émanant des établissements d'enseignement et de recherche français ou étrangers, des laboratoires publics ou privés. 


\title{
Introduction to the Special Issue - Land and Real Estate Development in the Greater China
}

\author{
Land and Real Estate in Northeast Asia, \\ New Approaches in an Era of Financialization
}

\author{
Natacha Aveline-Dubach
}

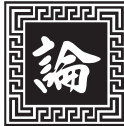

This special issue brings together three papers addressing the urban outcomes of real estate investment in China, Taiwan and Hong Kong. These countries/

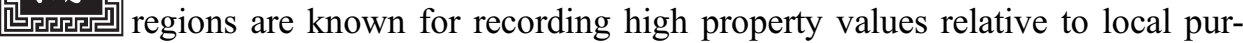
chasing power in their main urban areas. Price-to-income ratios in the residential sector range from 15 in Taipei to 35 in Hong Kong and Chinese tier-one cities such as Beijing and Shanghai. ${ }^{1}$ Yet critical home unaffordability is nothing new in Northeast Asia. In the 1980-1990s, a series of property booms previously raised concern in the region. Japan started to experience a "land bubble" of considerable magnitude from 1985 to 1991, whilst at the same time, Hong Kong and Taiwan were subject to substantial increases in property prices. Soon after, several Southeast Asian countries started to experience unexpected inflation in their property markets, which led to the eruption of the "Asian crisis" (1997) as a result of real estate turmoil in Thailand. These boom-bust cycles were caused by the massive supply of bank lending to real estate resulting from the liberalization of financial markets in East Asian countries (Aveline-Dubach \& Li, 2004; Dehesh \& Pugh, 2000; Mera \& Renaud, 2000). It was also found that Japan had

\footnotetext{
Natacha Aveline-Dubach is CNRS research director, affiliated to the laboratory Geographie-cités (University Paris I Panthéon-Sorbonne). Her recent work addresses the urban outcomes of the demographic transition and financialization of real estate, especially in Northeast Asia. She can be reached at <aveline@jp.cnrs.fr>.
}

\footnotetext{
${ }^{1}$ Source from $<$ https://www.numbeo.com/cost-of-living/ $>$.
} 
"exported" its domestic land bubble in Southeast Asia by fueling local property markets with international loans to local banks (Amyx, 2000; Werner, 1994).

Since then, two major changes have taken place. First, new financial channels have been established in a large number of countries to enable finance capital to have a stake in the flourishing (re)development of major city-regions (Corpataux \& Crevoisier, 2005; Halbert, Henneberry, \& Mouzakis, 2014; Savini \& Aalbers, 2015). This process of real estate financialization is unfolding through investment vehicles that target a range of urban objects (buildings, infrastructure, and public facilities) with diverse risk-return profiles and time frames. Northeast Asian governments did not initially show great enthusiasm for developing financial channels in their domestic real estate industries, except in the case of Hong Kong. Yet after a period of adjustment, some countries have come to embrace Anglo-American financial norms and to develop them in the property sector. This is the case of Japan and South Korea where property investment vehicles such as equity funds or real estate investment trusts (REITs) are experiencing rapid development (Aveline-Dubach, 2014). Other countries such as China and Taiwan have been more reluctant to open up their domestic real estate markets to foreign investment through these global circuits of finance. Yet a process of real estate financialization of an informal nature is currently unfolding in China, as evidenced by Theurillat, Lenzer Jr., and Zhan in this special issue. Therefore, analyzing the urban outcomes of financial investment in real estate is becoming increasingly complex given the multifarious ways through which investors' capital penetrates the urban built environment.

A second major change is the decline in Japan's dominant position as a regional financial center and driver of economic development in East Asia. China has now emerged as a major regional player, not only as a main trading partner of East Asian countries, but also as a top player in the regional real estate markets. According to a report quoted in the Nikkei Asian Review, in 2016 China invested 36.5 billion US dollars in income-producing properties in the Asia-Pacific region, ranking as the world's fourth biggest market worldwide after the US, Germany and the UK. ${ }^{2}$ Chinese investors' appetite for offshore real estate strongly contributed to the sharp rise in property prices in Hong Kong from 2008 onwards, driving the SAR as the world's priciest home market.

China's rise to global property superpower has obviously been supported by booming real estate markets at home. Urban scholars have shown particular interest in

\footnotetext{
${ }^{2}$ Nikkei Asian Review, April 14, 2017. http://asia.nikkei.com/Markets/Property/China-to-keep-top-place-inAsia-s-real-estate-investment-market-says-RCA
} 
the Chinese political economy of land, and developed a significant body of literature. Several authors have tried to grasp the relations between the state and land markets through the prism of Western concepts such as the "entrepreneurial city" (Chien \& Wu, 2011; Wu, 2003; Zhang, 2010), "neoliberal governance" (He \& Wu, 2009) and growth coalitions (Zhu, 1999). At the same time, the idiosyncratic character of the Chinese property-led capital accumulation regime has led to new theorizations. In particular, financial aspects of land supply and land collateralization relating to local government debt have been conceptualized inter allia as "land-centered" or "landed" urbanization (Lin, 2014; Ye \& Wu, 2014), "urban-centered accumulation" (Hsing, 2010) and "speculation-oriented urban entrepreneurialism" (Chien, 2013). Yet the interactions between land supply and real estate development have remained surprisingly under-studied.

\section{The Land/Real Estate Nexus, a Challenging Brainteaser}

There should be no major distinction between land and real estate in our understanding of urbanization, as land is a fundamental component of real estate, and real estate is in turn a major determinant of property value formation in built-up areas. Yet the academic literature clearly puts boundaries between land studies and real estate studies.

Land studies have a very old history, dating back to the 18th century when agriculture was the main source of income. Back then, the determination of land value was a major scientific issue given the need to design adequate taxation schemes for wealth redistribution. In fact, the theoretical debate was even to lead to the emergence of modern economic science as a distinct scientific discipline (Guigou, 1982). However, now that agricultural land has become urban in many places, involving it in speculative mechanisms of considerable magnitude, economists have almost deserted the field. Instead, land studies are primarily being developed by geographers, sociologists, and political scientists. The obvious reason is that land is not a "pure" commodity with transparent and accurate transaction records. Land values are shaped by property rights and land-use regulations pertaining to spatially fixed objects (Harvey, 1978). Therefore, there is no such thing as a single land market, but rather highly fragmented and opaque sub-markets that often do not behave according to the "market rationale." Land studies also tend to focus on countries where land markets are the most socially and politically embedded — that is to say, where understanding of land tenure, access and utilization is the most challenging - in Africa and SouthAmerica, but also in Asian countries such as India and China. However, urban scholars 
involved in land studies generally do not engage with real estate, nor do they provide in-depth analysis of the economic aspects of land.

On the other hand, real estate studies show a totally different picture. Contrary to land, real estate has the attributes of a commodity. This is all the more true now that we are witnessing the proliferation of financialized instruments aimed at enhancing the mobility/liquidity of real estate assets on a world scale (Corpataux \& Crevoisier, 2005). The financialization process, along with the development of information technologies, has also considerably increased the transparency of property markets. Access to newly developed datasets has encouraged mainstream economists to apply their models and valuation techniques to real estate, thus giving rise to a new strand of literature in real estate economics. This scholarship focuses on the performance of the various property investment tools, and assesses the added value of real estate in financial portfolio management. Although it contributes to the understanding of macro-scale dynamics in real estate markets within increasingly volatile economic contexts, it does not take into account the political and economic environments in which changes in property values take place. Real estate is apprehended as a purely financial asset, disembodied from the processes and players that shape the materiality of the urban built environment (Theurillat, Vera-Büchel, \& Crevoisier, 2016). Building on the modern portfolio theory, findings are primarily geared to institutional investors and ignore the urban and social outcomes of property investment.

In the face of increasing difficulties in grasping the logic of capital accumulation in financialized real estate economies, many urban scholars have been tempted to rely on the "capital switching" theory formulated by David Harvey (Harvey, 1982). However, this conceptualization of an alternative circulation of capital from a primary circuit (industrial production) to a secondary circuit (infrastructure and housing) as a way of fixing accumulation crises is not a very persuasive explanation in the case of Northeast Asia. As we are reminded here by Theurillat et al. in this special issue, property development is often used as a support to trigger economic growth in the region. This is typically the case of "property states" (Haila, 2000) such as Hong Kong and Singapore, and more broadly, a feature of East Asian developmental states. Furthermore, the built environment not only absorbs capital from the production sector but increasingly from other sources as well, including "hot money" from quantitative easing policies and households' retirement/precautionary savings collected by institutional investors in rapidly ageing societies (Fernandez \& Aalbers, 2016).

Another limitation of Harvey's paradigm is that it takes little account of the mediatory process operated by property players in fixing capital onto urban objects (Haila, 1990; Healey \& Barrett, 1990). These processes are taking increasingly 
diversified forms as financial channels expand, giving rise to unprecedented institutional arrangements between the real estate industry, the financial industry, the state, and other corporate players such as infrastructure providers.

Lastly, there is a general tendency to underestimate the active management of public properties by the state. The scholarship on "entrepreneurial" or "neoliberal" cities rightly points out the use of public land to provide financial resources to underfunded municipalities, or to enhance local competitiveness through the development of flagship urban projects. However, public properties are no longer managed exclusively with the aim of supporting urban and regional development. They tend to be regarded as corporate assets, and are thus managed according to cost-effective principles and capital market discipline (Christophers, 2017). When public land ownership is the norm in a country, the picture is more complicated since the state must arbitrate between a broad set of conflicting goals. In some instances, the state can even act as the originator or catalyst of a property boom.

This special issue examines the management of public properties in political economies with diverse land tenure regimes (exclusive public land ownership in China and Hong Kong, private tenure with state-owned parcels in Taiwan) whose gradient of political accountability ranges from a low level (China) to a high one (Taiwan). It provides fresh insight into the land/real estate nexus from the perspective of capital circulation within existing and new financial channels in Northeast Asia.

\section{Pro-Cyclical Policies of Public Land Sales}

The first observation that can be drawn from the papers is the high diversity of strategies and corresponding objectives pursued by local governments in selling public properties to private developers or investors. In all three cases, public assets are divested through competitive procedures, via auction/tender or initial public offerings, with the aim of ensuring fair competition, regulation or other mechanisms to protect the public interest. However, in practice, substantial distortion of these principles can be observed.

In the case of China, it is widely recognized that land supply procedures by local governments do not adhere to the rules of market value assessment and fair competition (Li, Chiang, \& Choy, 2011). Domestic players are highly favored, and among them, state-owned companies and private developers operating on a national basis are prominent bid winners (Theurillat, 2014). This is in line with the strategy of the Chinese state of limiting exposure of the country to systemic real estate crises, and keeping close control over the profits earned in the property sector (Aveline-Dubach, 
2017). In the light of "The Increasing Financialization of China's Urbanization" by Theurillat et al., it is clear that the Chinese public authorities have every reason to operate such a control. This paper gives an account of the large-scale land value capture operated by local states to finance the cost of urbanization. It provides a comprehensive framework that highlights the functioning of this capture mechanism from both the supply and demand side of land. Building on Wu's observations (Wu, 2015), the paper addresses the supply side by reporting how local governments sell land at cheap prices in urban peripheries to attract manufacturing industries and develop infrastructure through various types of investment platforms, then once urbanization has reached a certain level, sell serviced land to developers at its highest value so as to expand the reach of urban areas through infrastructure provision. The demand side of the land value capture mechanism is in turn documented with a comprehensive account of the financial circuits channeling capital from households, banks and financial markets - both formal and informal - to real estate development projects. A major driver of demand for land is the state policy that encourages households not only to purchase their home for their own occupation, but also to massively invest in real estate, either directly (by buying several properties) or indirectly (by allocating savings capital to investment vehicles). Once turned into major property investors, Chinese households have a broad spectrum of vested interests in booming real estate values, which explains why first-time homebuyers bear and endure skyrocketing housing prices. The lack of political accountability supports this model in which the authoritarian state activates an impressive set of levers to ensure flexible control of property markets through "just-in-time" remedial actions (AvelineDubach, 2017).

Although political accountability is of higher level in Hong Kong, it did not prevent an "en bloc" sale of 180 community retail and car-parking facilities in public estates run by the Hong Kong Housing Authority (HKHA). This transaction was concluded in 2005 through an initial public offering that established the first REIT structure in the Hong Kong stock exchange, the Link REIT. Although the government had claimed that this privatization would "return wealth" to the citizen via investment opportunities in the Link's shares, the handsome returns provided to shareholders through value extraction from welfare facilities were in practice limited to foreign and domestic institutional investors. As stressed in 'Embedment of 'Liquid' Capital into the Built Environment: The Case of REIT Investment in Hong Kong" by AvelineDubach, the purpose of the securitization process was not so much to balance the HKHA's budget but rather to strengthen Hong Kong's position as a major financial hub by extending its stock markets. Cost-efficiency in the management of public assets 
was also considered a priority in attracting foreign investors, which justified the disposal of so-called "non-core" assets by the Housing Authority. Following the dramatic increase in rents operated by the Link REIT in its refurbished shopping malls, daily necessities have become unaffordable for the older residents of many housing estates. Moreover, the Link has been allowed to divest its less profitable shopping malls and reallocate capital to new development projects. In so doing, it has realized sizeable capital gains to the detriment of housing estate residents. Despite repeated action against these violations of the Housing Ordinance by civil movements, the government has never departed from its strategy of protecting the interests of the Link's shareholders.

Taiwan's experience shows a similar approach by the government in favor of private interests, notwithstanding the democratic nature of the regime. In "The Missing Public Interest in Land: Auctions of Public Land in Taipei City," Lin and Cheng provide empirical evidence that the auction of public land in Taipei to property developers is operating against the public interest. Using a land development analysis, Lin and Cheng assessed the value of 26 parcels auctioned over the period 2006-2014 and compared these estimations to the actual auction prices. Their results indicate that public land is systematically sold below market value, with price premiums for developers amounting to $137 \%$ on average, and even $300 \%$ in some cases. What is more, a significant number of parcels remain idle for several years after the auction. This situation affects the residential conditions of Taiwanese households. Not only does the discount in land prices not translate into a supply of cheaper homes, but it encourages property developers to keep land undeveloped, thus pushing residential prices up. Such pro-cyclical effects on property markets are common to the three case-studies, regardless of the objectives of each national policy.

\section{Resistance against US-Designed Property Investment Vehicles}

A second significant finding of this special issue is the non-alignment of local real estate industries with newly developed global financial channels. The underlying factors of this reluctance to share the profits from real estate differ significantly across the cases.

In Hong Kong, although the government was keen to adopt REIT legislation and develop real estate securitization on its territory, local players have not really "played the REIT game." Apart from the very specific case of the Link, the "sponsor" 
groups of Hong Kong REIT structures have displayed passive management strategies, both in terms of building portfolio expansion and asset value enhancement. As pointed out by Aveline-Dubach, this is explained by the distinctive corporate governance of Hong Kong property groups. Contrary to their Japanese and Singaporean counterparts, these groups are predominantly family-based. Therefore, they are more likely to withhold quality-grade income-producing properties instead of divesting them onto external platforms, especially if they are expecting a continuation of the increase in property values. As a result, they tend to use REIT structures primarily to divest second-grade assets. This finding supports the recognition that the financialization of urban production is essentially mediated by local property developers (Guironnet, Attuyar, \& Halbert, 2016; Rouanet \& Halbert, 2015; Theurillat \& Crevoisier, 2014; Theurillat, Rérat, \& Crevoisier, 2015).

Another important factor underlying the weak development of Hong Kong REITs is the challenge to expand asset portfolios in the Mainland. As a gateway to China, Hong Kong was expected to develop investment opportunities across the border. Here again, China-based REIT expansion falls short of expectations by accounting for only $18 \%$ of the total H-REIT capitalization. Admittedly, Hong Kong family conglomerates have shown reluctance to divest their China-based assets, but the Chinese state has, for its part, imposed stringent rules governing the securitization of domestic properties. Cheung Kong Holdings, headed by the famous tycoon Li Kashing, is the only Hong Kong group to have ventured into a China-based REIT portfolio-building, with only three large-scale (thus "illiquid") quality-grade assets.

The Chinese state is indeed unwilling to develop instruments designed by Wall Street to invest in real estate. This has not, however, prevented the increasing financialization of the built environment, mainly via non-bank domestic investment channels.

According to Theurillat et al., this process was stimulated by the macro-economic policies implemented by the central state following the great financial crisis (GFC, 2008). These authors provide empirical evidence of the multifarious forms of financialized circuits that are channeling capital into urban production. They distinguish three main domains of financialization: urban infrastructure, property development, and urban property ownership. Following the GFC, the Local Financing Platforms (LFP) system aimed at financing urban infrastructure and services has been increasingly engaged in new financial circuits (bond markets, special purpose vehicles, trust finance) so as to benefit from the massive economic stimulus plan launched by the government in 2008-2009. On their side, property developers are also increasingly relying on financial channels to cover the cost of their real estate projects. Since bank 
loans are restricted to SOEs and big private developers, and corporate bonds to a few privileged top companies listed in Hong Kong, small and medium-sized developers are turning towards "shadow banking" in the form of trust and fund finance. Finally, households are now being encouraged to invest in rental property, in both residential and retail/hotel sectors, with rental incomes guaranteed by developers.

A significant share of these financial channels is not regulated and falls within the category of shadow banking. Although some circuits are very opaque and difficult to monitor, the Chinese state has chosen to permit the mushrooming of informal finance rather than exposing domestic property markets to global investment. Thus, it seems that China is currently experiencing new forms of real estate financialization that stand as an alternative to US-based standards. It remains to be seen whether this is a temporary or a long-term trend.

\section{Acknowledgment}

This special issue draws from the results of the "FINURBASIE" research project, which received the financial support of the French Research Agency (ANR) from 2012 to 2016 .

\section{References}

Amyx, J. A. (2000). Political impediments to far-reaching banking reforms in Japan: Implications for Asia. In G. W. Noble \& J. Ravenhill (Eds.), The Asian financial crisis and the architecture of global finance (pp. 122-151). Cambridge, England: Cambridge University Press.

Aveline-Dubach, N. (2014). New patterns of property investment in "post-bubble" Tokyo: The shift from land to real estate as a financial asset. In N. Aveline-Dubach, S.-C. Jou, \& M. Hsiao (Eds.), Globalization and new intra-urban dynamics in Asian cities (pp. 265-294). Taipei, Taiwan: National Taiwan University Press.

Aveline-Dubach, N. (2017). La centralité du foncier dans le régime d'accumulation du capital en Chine [The centrality of land in the capital accumulation regime in China], Revue de la Régulation, 21. Retrieved from https://regulation.revues.org/12262.

Aveline-Dubach, N., \& Li, L. H. (Eds.). (2004). Property markets and land policies in Northeast Asia: The case of five cities: Tokyo, Seoul, Shanghai, Taipei and Hong Kong. Tokyo \& Hong Kong: Maison Franco-Japonaise \& Center for Real Estate and Urban Economics, HKU.

Chien, S.-S. (2013). Chinese eco-cities: A perspective of land-speculation-oriented local entrepreneurialism. China Information, 27(2), 173-196. 
Chien, S.-S., \& Wu, F. (2011). The transformation of China's urban entrepreneurialism: The case study of the city of Kunshan. Cross Current: East Asian History and Culture Review, 1(1), 1-28.

Christophers, B. (2017). The state and financialization of public land in the United Kingdom. Antipode, 49(1), 62-85.

Corpataux, J., \& Crevoisier, O. (2005). Increased capital mobility/liquidity and its repercussions at regional level: Some lessons from the experiences of Switzerland and the United Kingdom (1975-2000). European Urban and Regional Studies, 12(4), 315-334.

Dehesh, A., \& Pugh, C. (2000). Property cycles in a global economy. Urban Studies, 37(13), 2581-2602.

Fernandez, R., \& Aalbers, M. B. (2016). Financialization and housing: Between globalization and varieties of capitalism. Competition \& Change, 20(2), 71-88.

Guigou, J.-L. (1982). La rente foncière, les théories et leur évolution Depuis 1650 [The land rent, theory and evolution since 1650]. Paris, France: Economica.

Guironnet, A., Attuyer, K., \& Halbert, L. (2016). Building cities on financial assets: The financialisation of property markets and its implications for city governments in the Paris city-region. Urban Studies, 53(7), 1442-1464.

Haila, A. (1990). The theory of land rent at the crossroads. Environment and Planning D: Society and Space, 8(3), 275-296.

Haila, A. (2000). Real estate in global cities: Singapore and Hong Kong as property states. Urban Studies, 37(12), 2241-2256.

Halbert, L., Henneberry, J., \& Mouzakis, F. (2014). The financialization of business property and what it means for cities and regions. Regional Studies, 48(3), 547-550.

Harvey, D. (1978). The urban process under capitalism: A framework for analysis. International Journal of Urban and Regional Research, 2(1-4), 101-131.

Harvey, D. (1982). The limits to capital. Oxford, England: Basil Blackwell.

He, S., \& Wu, F. (2009). China's emerging neoliberal urbanism: Perspectives from urban redevelopment. Antipode, 41(2), 282-304.

Healey, P., \& Barrett, S. M. (1990). Structure and agency in land and property development processes: Some ideas for research. Urban Studies, 27(1), 89-103.

Hsing, Y. (2010). The great urban transformation: Politics of land and property in China. Oxford, England: Oxford University Press.

Li, J., Chiang, Y.-H., \& Choy, L. (2011). Central-local conflict and property cycle: A Chinese style. Habitat International, 35(1), 126-132.

Lin, G. C. (2014). China's landed urbanization: Neoliberalizing politics, land commodification, and municipal finance in the growth of metropolises. Environment and Planning A, 46(8), 1814-1835. 
Mera, K., \& Renaud, B. (Eds.). (2000). Asia's financial crisis and the role of real estate. Abingdon, England: Routledge.

Rouanet, H., \& Halbert, L. (2015). Leveraging finance capital: Urban change and selfempowerment of real estate developers in India. Urban Studies, 53(7), 1401-1423. doi: $10.1177 / 0042098015585917$.

Savini, F., \& Aalbers, M. B. (2015). The de-contextualisation of land use planning through financialisation: Urban redevelopment in Milan. European Urban and Regional Studies, 23(4), 878-894. doi: 10.1177/0969776415585887.

Theurillat, T. (2014). The financing of urban production in China (working document). Retrieved from http://www2.unine.ch/socio/page24681.html.

Theurillat, T., \& Crevoisier, O. (2014). Sustainability and the anchoring of capital: Negotiations surrounding two major urban projects in Switzerland. Regional Studies, 48(3), 501-515.

Theurillat, T., Rérat, P., \& Crevoisier, O. (2015). The real estate markets: Players, institutions and territories. Urban Studies, 52(8), 1414-1433.

Theurillat, T., Vera-Büchel, N., \& Crevoisier, O. (2016). Commentary: From capital landing to urban anchoring: The negotiated city. Urban Studies, 53(7), 1509-1518.

Werner, R. A. (1994). Japanese foreign investment and the "land bubble." Review of International Economics, 2(2), 166-178.

Wu, F. (2003). The (post-) socialist entrepreneurial city as a state project: Shanghai's reglobalisation in question. Urban Studies, 40(9), 1673-1698.

Wu, F. (2015). Planning for growth: Urban and regional planning in China. New York, NY: Routledge.

Ye, L., \& Wu, A. M. (2014). Urbanization, land development, and land financing: Evidence from Chinese cities. Journal of Urban Affairs, 36(1), 354-368.

Zhang, L. (2010). The right to the entrepreneurial city in reform-era China. China Review, $10(1), 129-155$.

Zhu, J. (1999). Local growth coalition: The context and implications of China's gradualist urban land reforms. International Journal of Urban and Regional Research, 23(3), 534-548. 